\title{
In Memoriam of Dr Graham Polley
}

\section{Dominic C. Y. Foo ${ }^{1} \cdot$ Robin Smith ${ }^{2}$}

Published online: 27 May 2020

(C) Springer Nature Singapore Pte Ltd. 2020

\section{In Memoriam}

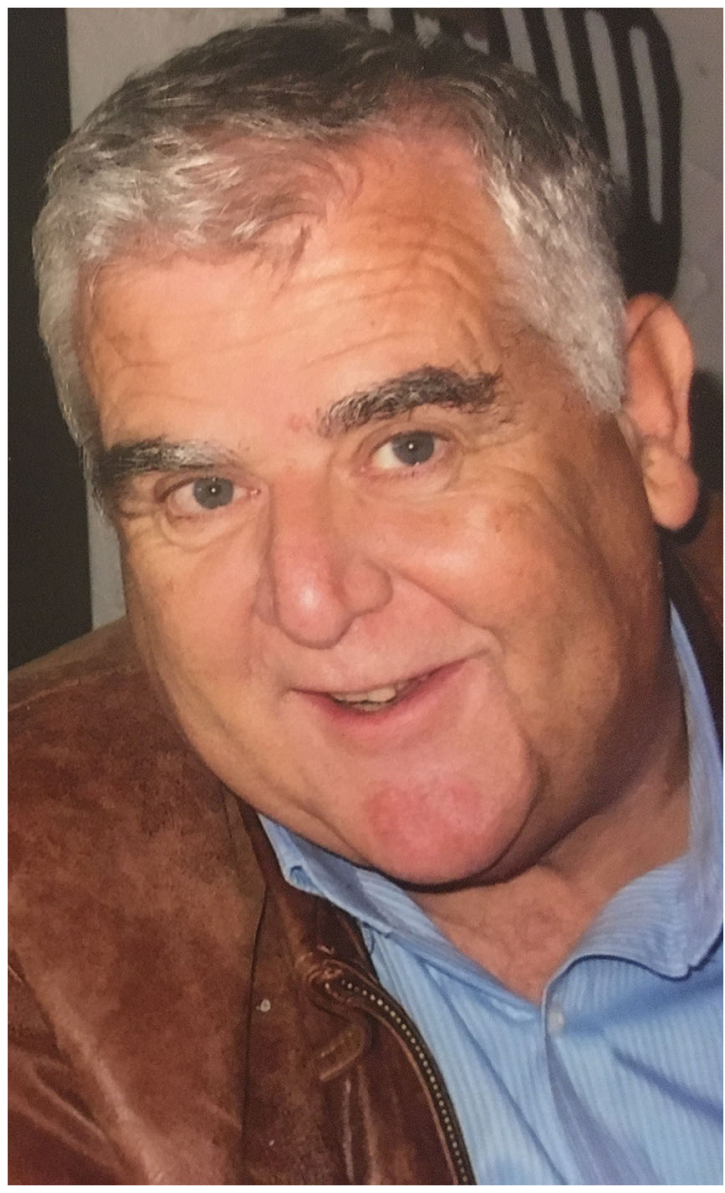

Graham T. Polley

1947-2018
In June 2018 the global community lost a key scholar in the area of Process Integration. This special issue in Process Integration and Optimization for Sustainability (PIOS) is to celebrate the influence and contribution of Professor Graham T. Polley, particularly in process integration.

Upon the completion of his $\mathrm{PhD}$ at Loughborough University, Graham started his career in the National Engineering Laboratories (NEL). He later moved into academia at the University of Strathclyde, University of Manchester Institute of Science and Technology (now University of Manchester) and University of Guanajuato in Mexico. Graham's scientific research output focused on heat transfer, heat exchanger design, and heat exchanger network synthesis. His paper published in year 1990 in Trans IChemE A (Chemical Engineering Research and Design), entitled 'Pressure drop considerations in the retrofit of heat exchanger networks' coauthored with M H Panjeh Shahi and F O Jegede won him the prestigious Moulton Medal with the Institution of Chemical Engineers (IChemE).

Interestingly, Graham's most cited paper in the scientific community is actually a magazine paper that he co-authored with his daughter Helen Polley in Chemical Engineering Progress in year 2000, entitled 'Design Better Water Networks'. Based on Scopus database, this paper has a total citation of more than 150 as of May 2020. Arguably, a vast majority papers in water minimisation, especially those reported new water pinch analysis methodology (published after year 2000) would have cited and made use of the example of this seminal paper that work on the fixed flowrate problem. The idea of this joint paper came about during the many discussions between father and daughter about Helen's research in enzymology and
Dominic C. Y. Foo

Dominic.Foo@nottingham.edu.my

Robin Smith

robin.smith@manchester.ac.uk
1 Department of Chemical and Environmental Engineering/Centre of Excellence for Green Technologies, University of Nottingham Malaysia, Broga Road, 43500 Semenyih, Selangor, Malaysia

2 Centre for Process Integration, School of Chemical Engineering and Analytical Science, The University of Manchester, Manchester M13 9PL, UK 
applications for wastewater from the textile industry. Helen also coordinated the production of Graham's website on pinch technology, where Graham's monthly papers became a useful archive for many professionals.

The papers in this special issue represent the main areas of Graham's scientific contribution, i.e. heat transfer and heat exchanger network, as well as water minimisation. Authors of these papers are mostly his ex-PhD students as well as colleagues in the scientific community in Process Integration.

\section{Tribute to Graham Thomas Polley \\ by \\ Martín Picón Núñez \\ Department of Chemical Engineering, University of Guanajuato, Mexico}

I count myself among the many fortunate people who had the opportunity of knowing Graham Polley not only as a professional but as friend. It is an honour for me, to write these few lines in gratitude and recognition to his academic and human contributions. He not only guided me at the inception of my $\mathrm{PhD}$ studies at UMIST, but also, very generously guided me as if I were a member of his own family, even many years after my graduation. Graham was a man with a big heart who always found the way to assist anyone who would approach him for help; not only his own countrymen, but also those coming to the UK from overseas. Something that really struck me right from the moment I met him was his passion for life, his passion for his family and his passion for Chemical Engineering and particularly heat exchangers.

From a young age, Graham was somehow related to the chemical process industries. His father took a position with Glaxo in Ulverston, Cumbria, UK. Years later, his interest in processing industries brought him back to Glaxo but now, in a different way, as he was involved in the design of a solvent recovery column as part of his MSc project. After graduating with his $\mathrm{PhD}$ from Loughborough University, in the Midlands, Graham joined the National Engineering Laboratories (NEL). After some years, he went back to academia joining Strathclyde University. In the early 1980s, Graham moved to the Centre for Process Integration in Manchester, where he served as research director. There, he demonstrated his passion for heat exchangers, heat recovery systems and process integration techniques by venturing into the concept of detailed heat exchanger design and process integration through the consideration of pressure drop. Later he also worked to consolidate the connections between heat transfer intensification techniques and process integration, work that he developed very closely with $\mathrm{Cal}$ Gavin Ltd. His contribution brought Process Integration an even stronger practical sense. The practical approach adopted by Graham was underlined by a long period of financial support from the Engineering Sciences Data Unit (ESDU). During the last part of his academic carrier he devoted himself to developing both, theory, and models of fouling in crude oil processing, liking it again to heat exchanger network design. His academic breakthroughs were recognized by the Chemical Institution of Chemical Engineers who awarded him the prestigious Moulton Medal in 1990. Later, in 2001, he became the president of the UK Heat Transfer Society. Towards the last part of his life, Graham joined the University of Guanajuato in Mexico as a full professor, where he further dedicated his time to the training of future researchers, supervising $9 \mathrm{PhDs}$ students.

Graham was a great teacher, father to five children, grandfather to 8 children and a beloved husband to his wife, Linda. Graham made many good friends from many parts of the world. I will always remember his enjoyable company. His personality reflected the strong character of a man determined to protect those around him, but at the same time, cheerful and mischievous. I am sure that, like me all of us who met him so closely, are missing him deeply.

\section{Tribute to Graham Thomas Polley \\ by \\ Robin Smith \\ The University of Manchester, UK}

I first met Graham Polley in the late 1970s when he was working at the then National Engineering Laboratory in East Kilbride. The first thing that struck me was his infectious enthusiasm to study heat transfer. That enthusiasm stayed with him throughout his life. Later, after a spell at Strathclyde University, we became colleagues when he joined the Centre for Process Integration at UMIST (now the University of Manchester). His years at the Centre for Process Integration allowed him to bring together his passion for heat transfer with the quest for new approaches to process integration. The success of this endeavour was endorsed by the award of the Moulton Medal of IChemE in 1990 for a paper on the retrofit of heat exchanger networks. He made major academic contributions in the application heat exchanger models to the analysis of heat exchanger networks. He also pioneered the exploitation of heat transfer intensification and fouling mitigation in heat recovery systems. In addition to his work in heat transfer, he will also be remembered for his contribution to water system design. During his years in the Centre for Process Integration we became friends and I developed a great respect for his caring approach to the supervision of students. He seemed to be energized by teaching others. Throughout the years we worked together he showed great leadership to those around him and was always willing to lend a helping hand. Aside from his great professional contribution, Graham remained at heart a family man. This struck me profoundly when I attended the wedding of one of his daughters. He will be sadly missed, but his contribution will endure.As children Dad encouraged us to be curious 
Tribute to Dad

by Helen Polley

Furness College, Barrow in Furness, England

and to look for solutions to any problems we encountered. He was a competitive player of every game, provoking in us a steely determination to get the better of him-eventually.

Dad's traits extended to our academic endeavours. He repeatedly told us that all qualifications were about 'grit' and stubbornness and not simply a result of the intellect you were fortunate enough to inherit. We knew that if we sought his help with a homework question, then we had better know our facts. Dad's homework assistance always came with one or two probing questions to help us work out answers for ourselves.
Dad has not only given us academic support, he has left us with a love for each other, our planet and society. His love for the Lake District brought a fascinating mixture of guests to our homes and his extensive travels, with our mum, brought us many weird and wonderful gifts and surprises.

The fact that my own scientific interests collided with my Dad's field of expertise is something that I will always treasure. Dad was a committed teacher and he has inspired in me a love for the teaching profession.

Dad nurtured us as he nurtured so many with love, with integrity and with lots and lots of humour.

Helen Rastelli (nee Polley), Sarah Polley, Angharad Polley and Matthew Graham Polley.

Publisher's Note Springer Nature remains neutral with regard to jurisdictional claims in published maps and institutional affiliations. 